\title{
RANCANG BANGUN MESIN PENGERING UNTUK PENGERINGAN LIMBAH SEAFOOD
}

\author{
Vendi Hermawan ${ }^{1}$, Hari Purnomo ${ }^{2}$ \\ Magister Teknik Industri, Fakultas Teknologi Industri, Universitas Islam Indonesia ${ }^{1,2)}$, \\ Jl. Kaliurang KM 14,5, Sleman, Yogyakarta, 55584 \\ E-Mail:Vendihermawan08@gmail.com,
}

\begin{abstract}
This Seafood waste drying process is still using a manual dryer that works with solar heat. This study uses a participatory method in its implementation using FGD (Focus Group Discussion) involving researchers, local communities, stakeholders and experts. From interviews with local residents, Trisik Beach locals problems is obtained, which is the humongous amount of seafood waste. Thus the researchers create a waste dryers tool that's easy to use, easy to maintainen, easy to operate, and made using inexpensive materials. Components of this tool include the buffer dryer, pulleys parabolic player, parabola, and a drying rack. Buffer serves as a buffer parabola, a drying rack, and stand pulleys parabola player. The function of pulley parabolic player is as a pointing control, so that the solar heat focus point can be obtained. While the parabola serves to reflect the solar cell to the drying rack so that the heat is evenly distributed. Drying rack consists of 6 shelves that serves to put the waste. Thus building a tool that efficiently practical, economical and ergonomic.
\end{abstract}

Keywords : Waste, Tools Drying, Participatory Method, FGD.

\section{PENDAHULUAN}

Limbah seafood merupakan bahan buangan tidak terpakai dari hasil pengolahan seafood yang berdampak negatif terhadap masyarakat jika tidak dikelola secara baik. Limbah seafood merupakan jenis limbah dengan karakteristik limbah padat (PPRI, 1999). Limbah seafood merupakan limbah padat berupa kepala, kulit, cangkang, ekor, dan duri. Limbah tersebut mudah sekali busuk, menimbulkan bau dan polusi semakin kuat bila kontak dengan air (Jenie dan Rahayu 1993). Limbah ikan dapat menjadi sumber penyakit menular, akan tetapi dapat juga diolah menjadi pakan ternak (Siswati, et al., 2010). Permasalahan tersebut dibutuhkan suatu rancangan alat yang dapat digunakan untuk proses pengeringan sehingga tidak mencemari lingkungan dan dapat meningkatkan nilai tambah limbah seafood.
Pengeringan didefinisikan sebagai proses pengeluaran kandungan air atau pelarut lainnya dari zat padat menggunakan penguapan (Greensmith, 1998). Proses ini dipengaruhi oleh suhu, kelembaban udara, kecepatan aliran udar, kandungan air, energi pengering, dan kapasitas pengering (Setyoko, et al., 2012). Oleh karena itu diperlukan alat tepat guna untuk memproses pengeringan.

Burlian dan Firdaus (2011) mengkaji alat pengering tenaga surya tipe box yang dapat meningkatkan efisiensi. Rancangan alat pengering limbah seafood ini menggunakan energi matahari dengan kolektor sinar berbentuk parabola. Penangkapan sinar matahari dengan tipe parabola mempunyai kemampuan maksimum. Meskipun matahari bergerak tidak berpengaruh secara signifikan pada kemampuan mengumpulkan cahaya matahari (Suwito dan Darsopuspito, 2013). 
Dengan didapatkan energi maksimum pengumpulan energi matahari melalui parabola diharapkan pengeringan limbah seafood bisa berjalan dengan optimal. Berbagai penelitian terkait dengan alat pengering telah banyak dilakukan. Penelitian alat pengering antara lain: Rancangan alat pengering jagung dengan tipe cabinet dryer (Napitupulu dan Atmaja, 2011), sistem pengering kerupuk ikan (Yuliati dan Santoso, 2012), pengering mie ramah lingkungan (Setyanto, et al., 2012), prototype buka tutup atap otomatis untuk pengeringan proses produksi berbasis mikrokontroler (Anas, 2010), prototype kolektor surya tipe plat datar pada pengering produk pertanian dan perkebunan (Arikundo dan Hazwi, 2014). Sedangkan penelitian lain adalah pengeringan biji pala berbasis logika fuzzy (Putra dan Sumarjan, 2014), alat pengering ubi kayu tipe rak (Thamrin dan Kharisandi, 2011), alat pengering efek rumah kaca dengan bantuan tungku biomassa (Hadi, 2015), alat pengering limbah ikan dengan metode Quality Function Deployment (Ahmad, 2015). Rancangan alat yang telah dilakukan perlu dilakukan perbaikan agar lebih efektif dan efisien.

Penelitian yang dilakukan dengan melibatkan pengguna dalam merancang dengan konsep partisipatori. Konsep ini telah berhasil dalam berbagai perancangan seperti rancangan seperti perawat orang tua (Rasmussen, et al., 2017), prototipe alat pemantauan kesehatan untuk penyakit produksi sapi (Duval, et al., 2016), mengurangi cedera pada pustakawan (Yuan, 2015).

Keberhasilan konsep partisipatori dari berbagai penelitian diharapkan juga dapat mendesain alat pengering yang sesuai dengan keinginan pengguna. Pada penelitian ini menggunakan konsep partisipatori ergonomi.
Pengambilan data dengan FGD untuk memperoleh informasi yang akurat tentang kondisi di lapangan, sehingga mampu memberikan solusi yang tepat dalam pengolahan limbah dan mampu merancang alat yang sesuai dengan keinginan pengguna.

\section{METODE PENELITIAN}

Metode yang digunakan dalam perancangan alat pengering ini menggunakan metode partisipatori. Penggunaan metode partisipatori ini diharapkan mampu memecahkan masalah dan memberikan solusi kepada pengguna.

\subsection{Tempat Penelitian}

Penelitian ini dilakukan di pantai Trisik Kecamatan Galur Kabupaten Kulon Progo Daerah Istimewa Yogyakarta.

\subsection{Pendekatan Partisipatori}

Konsep partisipatori merupakan metode perancangan yang melibatkan secara dini para stakeholder. Langkah-langkah penyelesaian konsep partisipatori adalah (Jong and Vink, 2000) :

1. Identifikasi anggota partisipatori.

Langkah ini dilakukan untuk menentukan anggota partisipatori. Dalam hal ini anggota partisipatori adalah para stakeholder yang terlibat dalam paguyuban rumah makan.

2. Menentukan anggota partisipatori.

Pada tahap ini dilakukan untuk menentukan jumlah anggota yang terlibat. Anggota yang dilibatkan dalam partisipatori adalah orang yang betulbetul menguasai masalah.

3. Pengembangan dan perencanaan.

Pada langkah ini dilakukan pertemuan atau FGD anggota partisipotori untuk menentukan spesifikasi dan analisis masalah, membuat dan memilih ide, mengembangkan konsep dan merancang produk. 
4. Uji coba produk

Langkah terakhir adalah melakukan uji coba alat oleh anggota partisipatori dan dilanjutkan oleh pengguna. Jika ada kekurangan maka dilakukan perbaikan dengan mempertimbangkan masukanmasukan dari pengguna.

\subsection{Prosedur Penelitian}

\subsubsection{Wawancara awal}

Wawancara dilakukan untuk menggali informasi secara langsung kepada warga sekitar Pantai Trisik dari pihak yang terkait dalam proses penunjang pembuatan alat pengering limbah. Wawancara meliputi, wawancara kepada warga sekitar dan kepada pemilik rumah olahan yang berbahan dasar seafood. Pertanyaan yang diajukan adalah banyaknya limbah seafood yang terbuang. Sedangkan untuk karyawan adalah berapa banyak seafood yang diolah dan berapa banyak limbah yang dihasilkan. Hasil wawancara ini kemudian dijadikan acuan awal topik diskusi pada tahap diskusi kelompok.

\subsubsection{Diskusi kelompok}

Diskusi dilakukan sebagai upaya pembahasan lebih mendalam dengan cara tukar pendapat dan masukan dalam rangka mencari solusi yang diharapkan oleh seluruh pihak yang terlibat. Diskusi dilakukan diluar jam kerja dan dilakukan bertahap. Peserta diskusi melibatkan dua pihak yaitu warga sebagai pihak yang dirugikan akibat pencemaran limbah dan pemilik rumah pengolah seafood sebagai pihak yang memiliki usaha, sehingga dapat mengetahui segala bentuk kendala dan solusi yang ingin dicapai. Untuk itu, peneliti selaku mediator yang berperan sebagai perancang dan aplikator hasil diskusi, dapat mewujudkan rancangan alat pengering yang sesuai dengan kebutuhan warga.

\subsubsection{Perancangan alat pengering}

Perancangan alat menggunakan konsep partisipatori dengan melibatkan anggota partisipatori yang terdiri ketua kelompok paguyuban, perangkat desa, pemilik rumah makan, ahli ergonomi, ahli teknik mesin dan bengkel. Rancangan alat pengering ini diharapkan benar-benar dapat di implementasikan kepada warga sekiar Pantai Trisik untuk mengolah hasil limbah seafood supaya memiliki nilai tambah dengan kualitas yang baik.

\section{HASIL DAN PEMBAHASAN 3.1 Observasi Lapangan}

Observasi lapangan dilakukan untuk mengetahui kondisi riil. Kondisi lapangan di Pantai Trisik sebagian besar merupakan penjual seafood segar yang tersebar disepanjang pantai. Angka pencapaian limbah seafood di Pantai Trisik rata - rata 25 kg per hari. Di Pantai Trisik terdapat empat pedagang ikan yang masing-masing pedagang mampu menjual ikan sebanyak 25 $\mathrm{kg} /$ hari di hari libur, bahkan jika pembeli ramai dapat mencapai $50 \mathrm{~kg} / \mathrm{hari}$. Untuk hari biasa pedagang mampu menjual ikan sebanyak 3-5 kg/hari. Selain itu terdapat satu rumah produksi olahan ikan menjadi oleholeh khas Pantai Trisik dengan total produksi mencapai $50 \mathrm{~kg} /$ hari dan satu rumah makan yang mengolah ikan mencapai 20 $\mathrm{kg} /$ minggu. Hasil observasi menunjukkan bahwa limbah seafood hanya dibuang begitu saja tanpa adanya pengolahan lebih lanjut. Berdasarkan data tersebut dirasa perlu adanya alat pengering tersebut.

Selanjutnya dilakukan diskusi untuk menggali informasi yang berkaitan dengan pembuatan alat pengering. Diskusi ini untuk mengetahui keinginan atau harapan warga sehingga dapat merancang alat yang sesuai dengan keinginan dan harapan. Dengan demikian akan mendapatkan alat yang berdaya guna praktis, ekonomis, dan ergonomis.

\subsection{Hasil FGD}

FGD melibatkan peneliti dengan kelompok paguyuban, perangkat desa, pemilik rumah makan, ahli ergonomi, ahli teknik mesin dan bengkel. Tujuan FGD membantu dalam mengatasi kendala dan keinginan dalam pembuatan alat pengering. 
Tabel 1. Tahapan diskusi

\begin{tabular}{|c|c|}
\hline \multicolumn{2}{|r|}{ Diskusi tahap 1} \\
\hline Permasalahan & Rencana perbaikan \\
\hline $\begin{array}{l}\text { Tidak tersedianya alat } \\
\text { pengolah limbah }\end{array}$ & $\begin{array}{l}\text { 1. Merancang alat pengering yang sesuai dengan keinginan } \\
\text { warga. } \\
\text { 2. Merancang alat dengan memanfaatkan tenaga panas } \\
\text { matahari. }\end{array}$ \\
\hline Lahan pengeringan & $\begin{array}{l}\text { Merancang alat pengering yang berupa rak bertingkat } \\
\text { sehingga mampu menanggulangi keterbatasan lahan. }\end{array}$ \\
\hline Kebersihan bahan & $\begin{array}{l}\text { 1. Merancang alat menggunakan bahan yang tidak mudah } \\
\text { berkarat } \\
\text { 2. Merancang alat yang mudah dibersihkan. }\end{array}$ \\
\hline Alat mahal & $\begin{array}{l}\text { 1. Merancang alat pengering dengan bahan recycle. } \\
\text { 2. Merancang alat dengan menggunakan bahan yang mudah } \\
\text { didapat. } \\
\text { 3. Merancang alat dengan biaya operasional rendah. } \\
\text { 4. Merancang alat pengering yang tidak membutuhkan tenaga } \\
\text { kerja yang banyak. }\end{array}$ \\
\hline $\begin{array}{l}\text { Pemanasan bahan yang } \\
\text { tidak merata }\end{array}$ & Merancang alat dengan menggunakan bahan semi konduktor. \\
\hline Teknis pengoperasian alat & $\begin{array}{c}\text { Merancang alat dengan puli sebagai penggerak parabola. } \\
\text { Diskusi tahap } 2\end{array}$ \\
\hline Permasalahan & Rencana perbaikan \\
\hline $\begin{array}{l}\text { Kurangnya sumber daya } \\
\text { manusia }\end{array}$ & $\begin{array}{l}\text { 1. Merancang alat pengering yang tidak menyulitkan } \\
\text { pengguna. } \\
\text { 2. Merancang alat pengering yang mudah digunakan. } \\
\text { 3. Merancang alat pengering yang mudah dalam } \\
\text { perawatannya. }\end{array}$ \\
\hline Aspek ergonomi & $\begin{array}{l}\text { 1. Merancang alat pengering yang ukurannya sesuai } \\
\text { pengguna. } \\
\text { 2. Merancang alat pengering yang aman ditinjau dari aspek } \\
\text { keselamatan dan kesehatan. }\end{array}$ \\
\hline Aspek waktu pemakaian & $\begin{array}{l}\text { Merancang alat pengering dengan waktu penggunaan jangka } \\
\text { panjang. }\end{array}$ \\
\hline
\end{tabular}

Diskusi tahap awal berupa jumlah limbah, jenis limbah dan bagaimana cara mengatasi masalah tersebut sehingga dapat dipecahkan bersama guna mencapai pembuatan alat pengering yang berkualitas sesuai dengan keinginan warga. Hasil tahapan diskusi terdapat pada Tabel 1.
Hasil FGD diinginkan alat yang ergonomis, murah, awet, tahan lama, semua orang bisa menggunakan, ramah lingkungan, tidak membutuhkan tempat yang luas dan tidak menggunakan bahan bakar untuk pengoperasian. Hal ini agar dapat mengurangi biaya produksi. Untuk mewujudkan keinginan warga, dibuat alat pengering yang berbentuk rak bersusun dengan bahan yang tidak mudah berkarat serta memanfaatkan sinar matahari sebagai sumber panas. 
Tabel 2. Evaluasi perbaikan perancangan alat pengering

\section{Pertemuan 1}

\section{Pertemuan 2}

Komponen pengering terdiri dari

1. Rak pengering menyesuaikan yang limbah.

2. Sistem pengering berupa panas matahari yang dipantulkan ke rak pengering.

3. Pemanas berupa parabola yang dilengkapi kaca sehingga dapat memantulkan ke rak pengering.
Komponen pengering terdiri dari : Hasil diskusi

1. Rak pengering yang didapatkan hasil menyesuaikan kapasitas limbah. yang baik dan

2. Sistem pengering berupa panas matahari yang dipantulkan ke rak pengering.

3. Pemanas berupa parabola yang dilengkapi kaca sehingga dapat memantulkan ke rak pengering.

Perbaikan penambahan puli yang berguna untuk menggerakakan parabola.

\section{Evaluasi} Tahap Akhir mencapai kata

mufakat

sehingga

mendapatkan

alat pengering

yang sesuai

dengan

keinginan

warga.

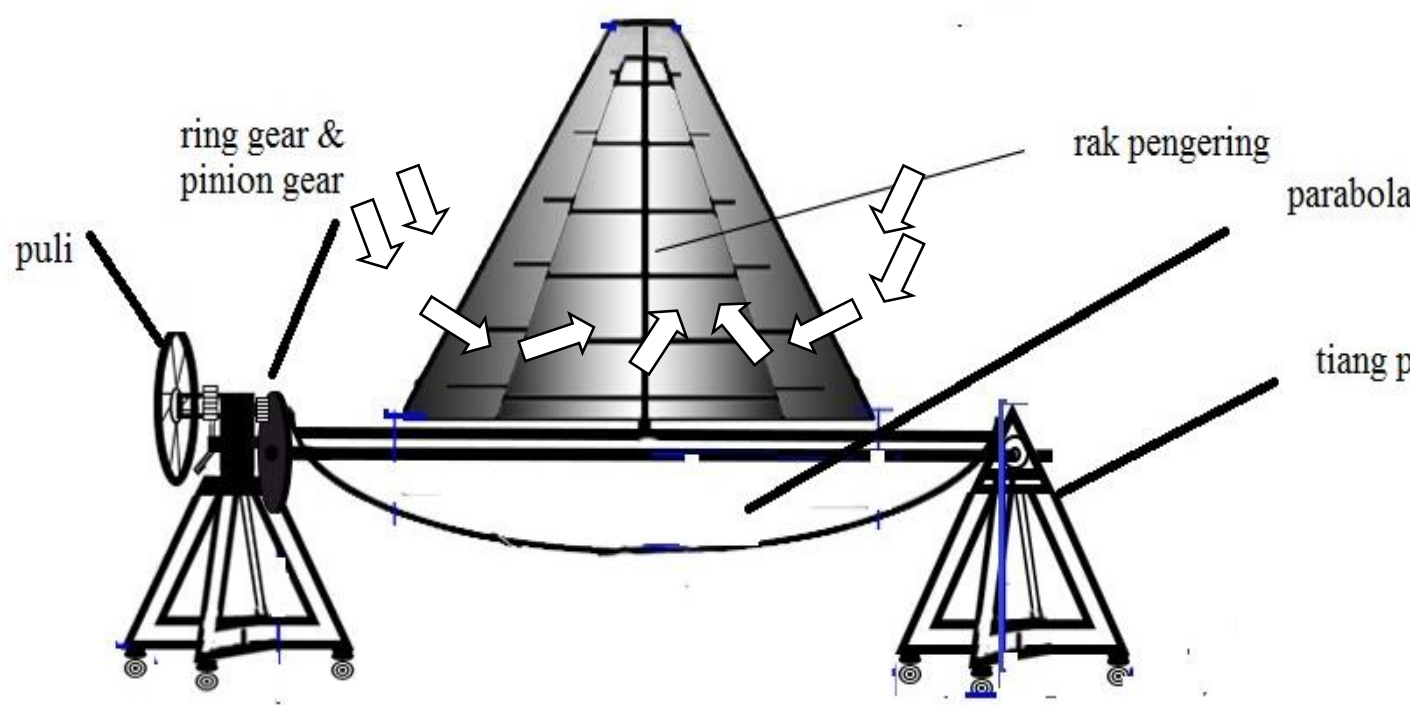

Gambar 1. Skema alat pengering.
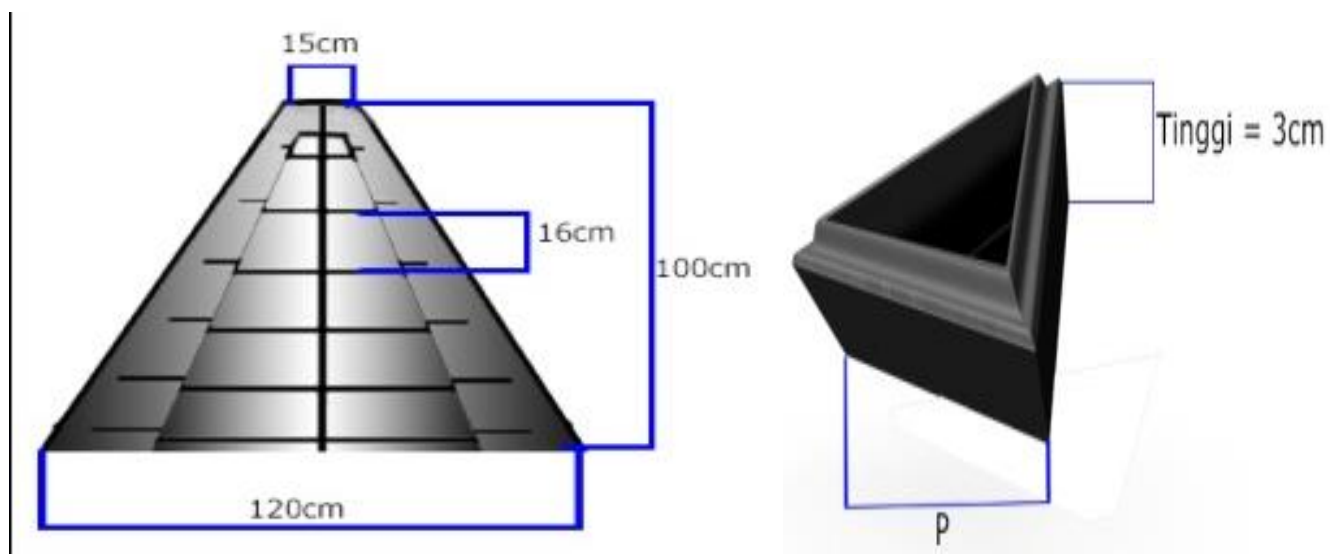

\section{Keterangan Loyang :}

$\mathrm{R} 1: 70 \mathrm{~cm}, \mathrm{R} 2: 55 \mathrm{~cm}, \mathrm{R} 3: 40 \mathrm{~cm}, \mathrm{R} 4: 25 \mathrm{~cm}$ $\mathrm{R} 5: 10 \mathrm{~cm}$.

Gambar 2. Rak pengering. 


\subsection{Hasil Perancangan}

Rancangan berdasarkan FGD dengan komponmen utama berupa ruang pemanas berbentuk parabola, ruang bahan yang dikeringkan berbentuk rak piramida. Hasil evaluasi yang telah dilakukan dengan para kelompok warga selaku obyek yang terkena dampak dari pencemaran limbah dan para stakeholder didapat evaluasi yang ditunjukan pada Tabel 2.

\subsubsection{Rak pengering}

Rak pengering berfungsi untuk penempatan bahan yang dikeringkan. Rak pengering terbuat dari rangka besi yang terdiri dari 6 tingkat berbentuk piramida, sehingga semakin keatas ruang pengering semakin mengecil.

\subsubsection{Parabola}

Alat ini terbuat dari besi yang dilengkungkan menyerupai parabola dengan panjang $144 \mathrm{~cm}$ diberi kaca yang disusun mengikuti bentuk parabola. Fungsi dari parabola ini untuk memantulkan panas matahari kedalam ruang pengering.

\subsubsection{Puli pembalik parabola}

Puli terbuat dari besi yang berdiameter $40 \mathrm{~cm}$ puli ini terdiri dari pinion gear dan ring gear. Puli ini berfungsi untuk menggerakkan parabola. Cara kerja puli yaitu dengan putaran tangan yang dihubungkan dengan gear. Sehingga dapat memutar parabola untuk menemukan titik fokus. Pemfokusan parabola diharapkan mampu mempercepat proses pengeringan limbah.

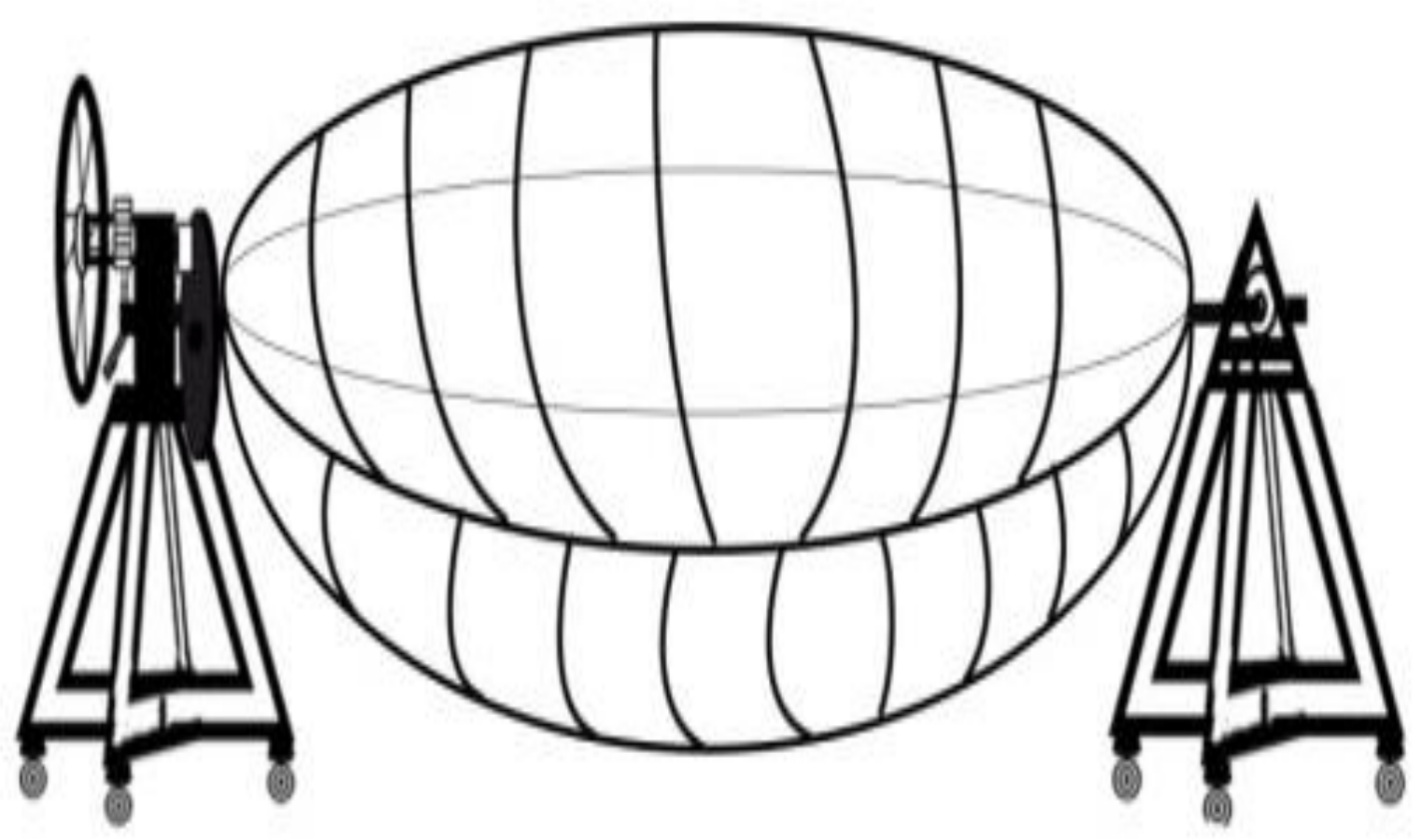

Gambar 3. Parabola. 


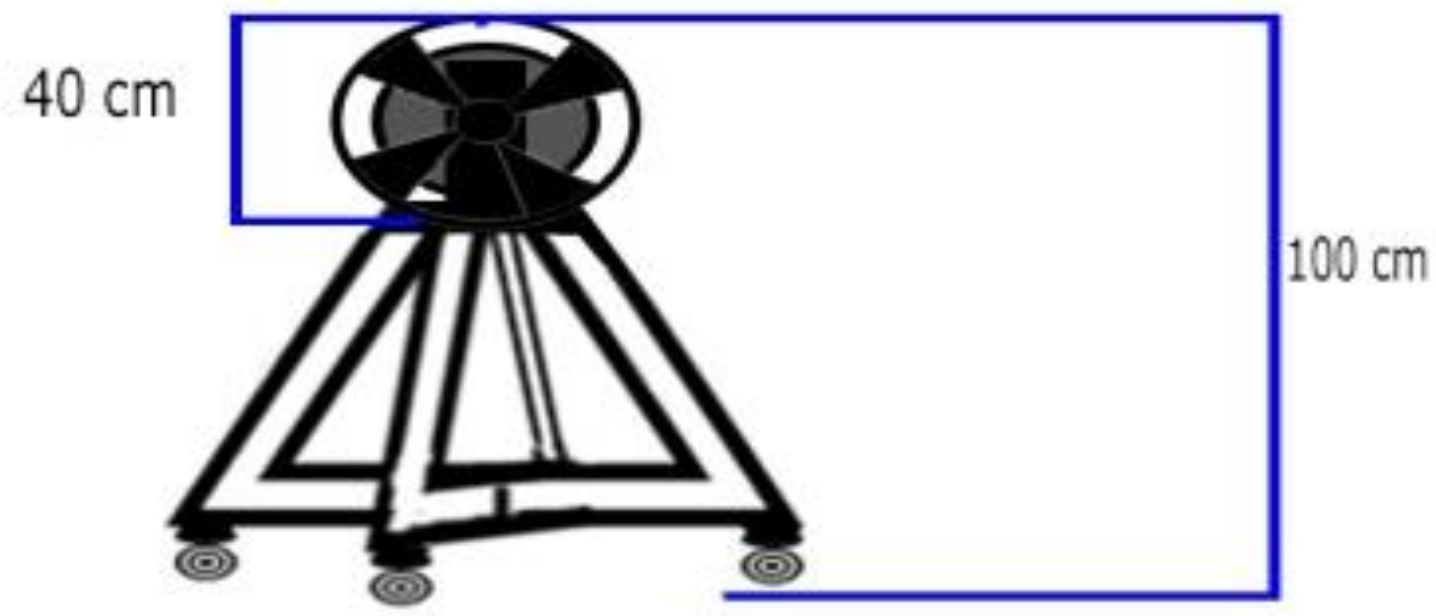

Gambar 4. Puli penggerak parabola.

\subsubsection{Sistem Pengering}

Sistem pengering komponen utama yaitu parabola dan rak pengering. Sistem pengering ini berfungsi sebagai pemanas bahan dengan cara kerja menangkap panas sinar matahari kemudian panas matahari dipantulkan ke ruang pemanas yang berbentuk piramida sehingga membentuk satu titik fokus. Dari titik fokus yang dicapai maksimal didapat hasil pengeringan yang merata.

\subsubsection{Dimensi Alat Pengering}

Dimensi alat pengering disesuaikan dengan dimensi tubuh pengguna agar alat yang dioperasikan dapat memberikan rasa nyaman dan aman. Hal ini, dapat menciptakan kondisi yang ergonomis guna meningkatkan produktifitas pekerja.

Alat pengering berbentuk parabola yang bertujuan untuk memantulkan panas matahari ke ruang pengering yang berbentuk piramida. Piramida tersebut memiliki enam tingkat rak pengering. Ukuran alat pengering ditunjukkan seperti pada Gambar 5 dan 6.

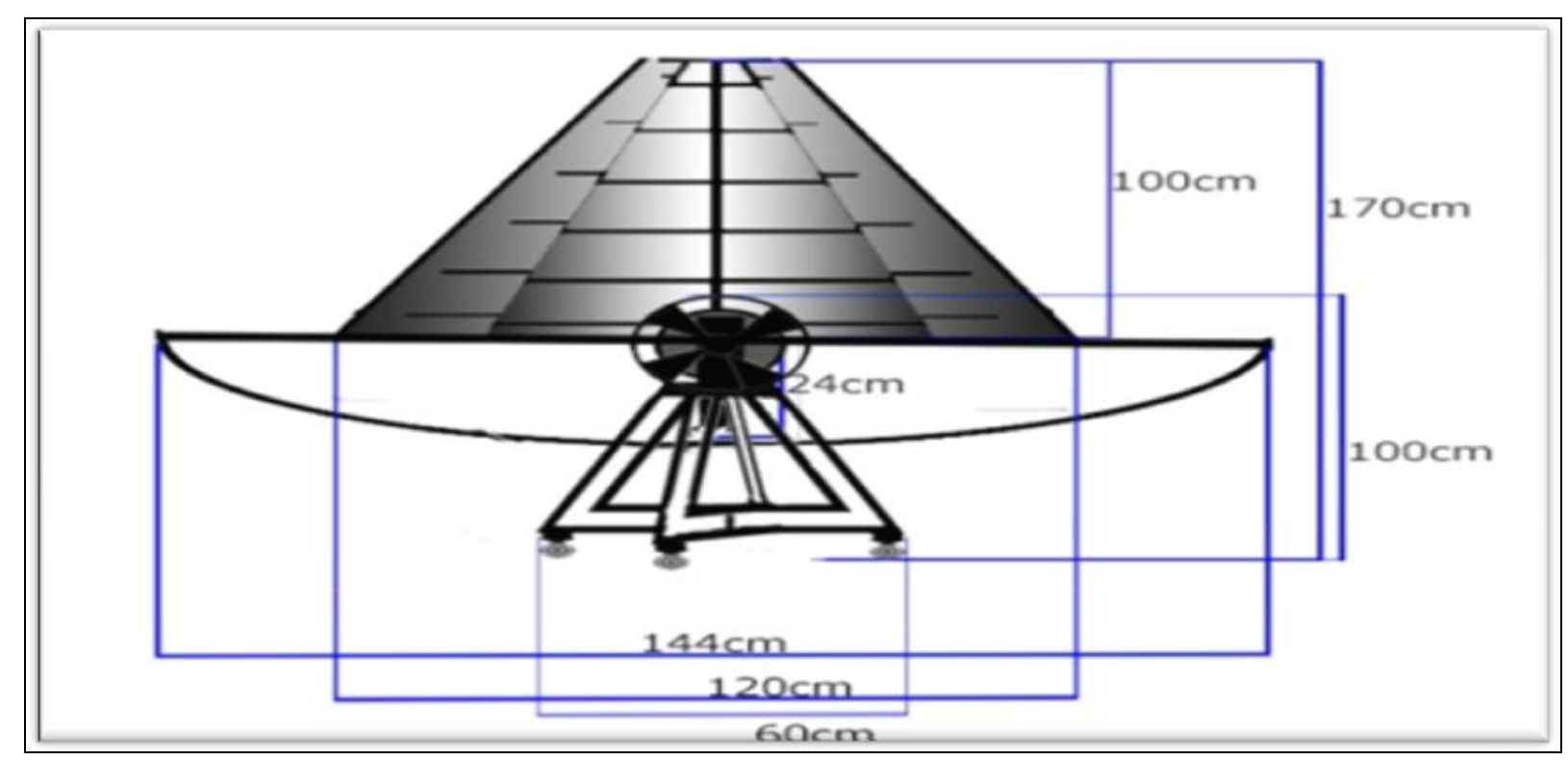

Gambar 5. Tampak samping. 


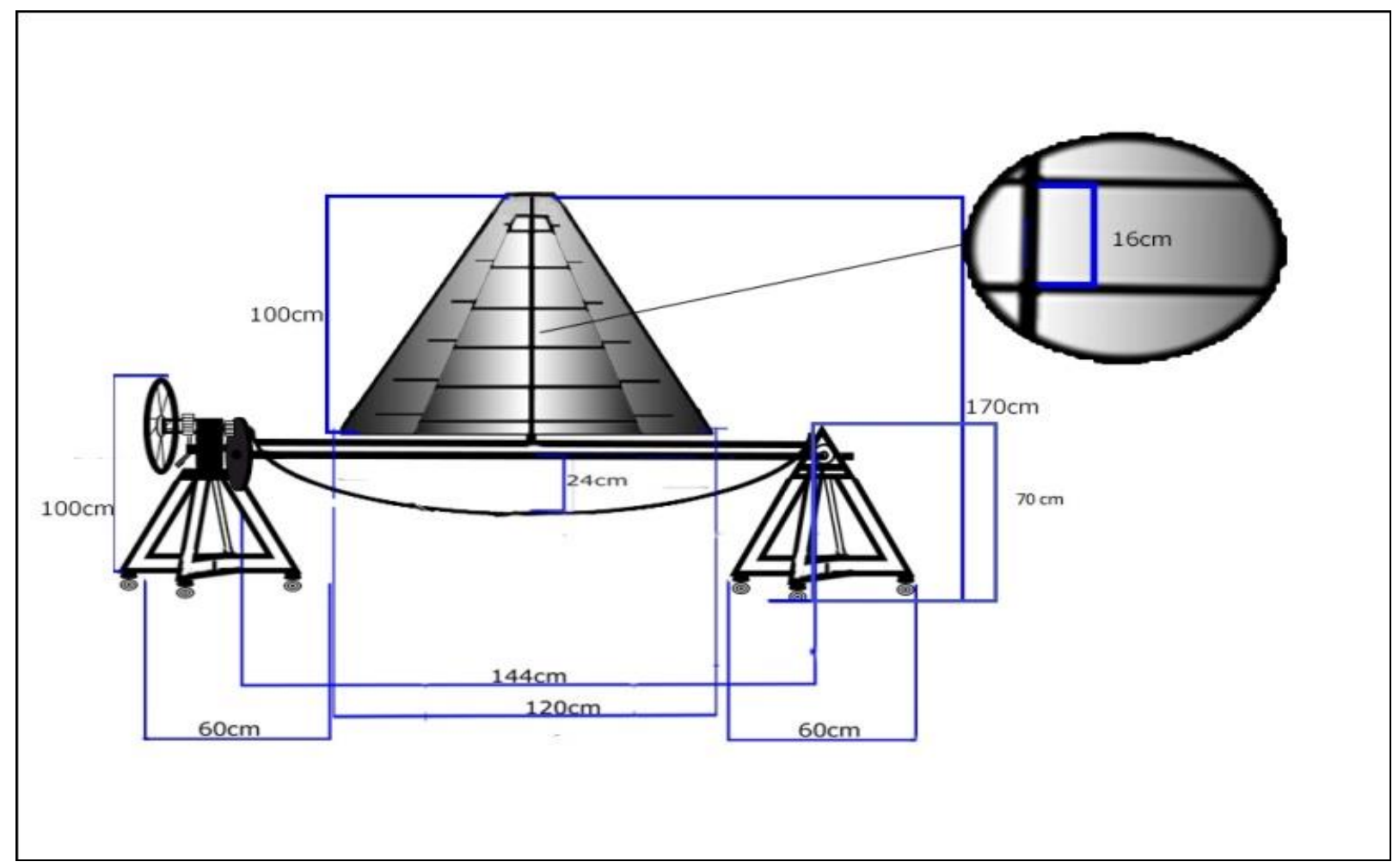

Gambar 6. Tampak depan.

\section{KESIMPULAN}

Limbah seafood merupakan limbah yang bersifat basah. Agar limbah tidak mencemari lingkungan maka perlu diolah dengan alat pengolah limbah. Hasil penelitian dengan metode partisipatori didapat alat yang berbentuk parabola sebagai kolektor panas dan rak pengering berbentuk piramida dengan 6 tingkat. Evaluasi alat dilakukan dua kali, dengan harapan dapat menciptakan alat yang lebih baik dan dapat digunakan secara maksimal. Penelitian ini diharapkan mampu menanggulangi dampak lingkungan di Pantai Trisik dan meningkatkan nilai tambah dari limbah seafood tersebut.

\section{DAFTAR PUSTAKA}

Ahmad, T., L., 2015. Rancang bangun alat pengering limbah ikan dengan Metode Quality Function Deployment (QFD) dan Design Experiment sebagai upaya meningkatkan nilai ekonomi pendapatan ukm ikan asap. Skripsi, Fakultas Teknik. Universitas Dian Nuswantoro Semarang.

Anas, R,, 2010. Rancang bangun prototipe buka tutup atap otomatis untuk pengeringan proses produksi berbasis mikrokontroler AT89S51. Tugas AKhir. Universitas Diponegoro.

Arikundo, F. R. \& Hazwi, M., 2014. Rancang bangun prototype kolektor surya tipe plat datar untuk penghasil panas pada pengering produk pertanian dan perkebunan. Jurnal eDinamis, Vol. 8, No 4. Hal. 194203. 
Burlian, F., \& Firdaus, A., 2011. Kaji eksperimental alat pengering kerupuk tenaga surya tipe Box menggunakan kosentrator cermin datar. Prosiding Seminar Nasional AVoER ke-3, Hal. 95-100.

Duval, J., E, Fourichon, C, Madouasse, A , Sjöström, K., Emanuelson, U., Bareille, N. , 2016. A participatory approach to design monitoring indicators of production diseases in organic dairy farms. Preventive Veterinary Medicine, 128, p. 12-22.

Greensmith, M., 1998. Practical dehydration. Woodhead Publishing, Ltd.

Hadi, S., 2015. Laju Pengeringan kapulaga menggunakan alat pengering efek rumah kaca dengan bantuan tungku biomassa. Jurnal Teknik Mesin, Vol 5, No.1, Hal. 49-58.

Jenie, B. S. L. \& Rahayu, W. P., 1993. Penanganan limbah industri pangan. Kanisius, Hal. 40-45.

Jong, A., M., de and Vink, P., 2000. The adoption of technologi innovation for glaziers : evaluation of a participatory ergonomics approach. International Journal of Industrial Ergonomics, 26, p. $39-46$.

Napitupulu, F., H. dan Atmaja, Y., P., 2011. Perancangan dan pengujian alat pengering jagung dengan tipe cabinet dryer untuk kapasitas $9 \mathrm{~kg}$ per siklus. Jurnal Dinamis, Vol. II, No. 8, Hal. 32-43.

PPRI. Peraturan Pemerintah Republik Indonesia No. 18 / 1999. Tentang Pengelolaan Limbah Bahan Berbahaya Dan Beracun, Jakarta.
Putra G., M., D. \& Sumarjan., 2014. Desain sistem kendali suhu dan RH berbasis logika fuzzy pada pengeringan biji pala (Myristica Sp.) Erk hybrid. Jurnal Ilmiah Rekayasa Pertanian dan Biosistem. Vol. 2, No 1, Hal. 13-19.

Rasmussen, C., D., N, Lindberg, N., K, Ravn, M., H, Jørgensen, M., B, Søgaard, K, Holtermann, A., 2017. Processes, barriers and facilitators to implementation of a participatory ergonomics program among eldercare workers. Applied Ergonomics. 58, p. 491-499.

Setyanto, N., W., Himawan, R., Zefry, D., Arifianto, E., Y., Puteri, R., M., S., Kurnia, N., 2012. Perancangan alat pengering mie ramah lingkungan, Jurnal Rekayasa Mesin, Vol. 3, No. 3, Hal. 411- 420.

Setyoko, B., Darmanto, S., Rahmat., 2012. Peningkatan kualitas pengeringan ikan dengan sistem tray drying. Prosiding Seminar Nasional Sains dan Teknologi Fakultas Teknik. Hal. 37-42, Semarang: Universitas Wahid Hasyim Semarang.

Siswati, N. D., Zain, A., Mohammad., 2010. Animal feed making from tuna fish waste with fermentation process. Jurnal Teknik Kimia, Hal. 309-313.

Suwito, A., O., P., dan Darsopuspito, S., 2013. Analisa performa kolektor surya tipe parabolic trough sebagai pengganti sumber pemanas pada generator sistem pendingin difusi absorpsi. Jurnal Teknik Pomits, Hal. 394-398. 
Thamrin, I. \& Kharisandi, A., 2011. Rancang bangun alat pengering ubi kayu tipe rak dengan memanfaatkan energi surya. Prosiding Seminar Nasional AVoER ke-3, Hal. 49-54.

Yuliati dan Santosa, H., 2012. Rancang bangun system pengering untuk pengrajin kerupuk ikan di Kenjeran. Prosiding Seminar Nasional Aplikasi Sains \& Teknologi (SNAST) Periode III Yogyakarta, Hal. B-179-B-184.

Yuan, L., 2015. Reducing ergonomic injuries for librarians using a participatory approach. International Journal of Industrial Ergonomics, 47, p. 93103. 